\title{
Ammattikorkeakoulun osaamisperustaisen opetussuunnitelman tulkintarepertuaarit
}

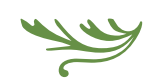

Osaamisperustainen pedagogiikka näyttää olevan ammattikorkeakouluissa vielä alkuvaiheessa. Myös aiemmin hankitun osaamisen tunnistamisen ja tunnustamisen ajatus on yhä vieras.

OSAAMISPERUSTAISUUS KÄSITTEENÄ ON Samaan aikaan sekä uusi että vanha. Ammatillisessa koulutuksessa osaamisesta on puhuttu jo parikymmentä vuotta, ja korkeakoulutukseen käsite saapui kymmenisen vuotta sitten. Osaamisperustaisen opetussuunnitelman kehittäminen korkeakouluissa pohjautuu Bolognan prosessin tavoitteisiin edistää Euroopan yhtenäisten työmarkkinoiden syntymistä ja työvoiman liikkumista. Unionin maiden koulutusjärjestelmien ja niiden tuottaman osaamisen harmonisointi on tärkeä keino tavoitteen toteuttamisessa.

Jatkuvassa muutoksen tilassa olevan työelämän osaamisen vaatimuksiin vastaaminen on ollut viime vuosien tavoite ammatillisessa koulutuksessa niin toisella asteella kuin ammattikorkeakoulussakin. Osaamisperustaisella opetussuunnitelmalla viitataan yleisesti opetussuunnitelmaan, jossa oppimisen tavoitteet kuvataan työelämässä tarvittavina osaamisina ja pätevyyksinä.

Osaamisperustaisuuteen liittyy vahvasti ajatus ajasta, paikasta ja tavasta riippumattomasta oppimisesta ja osaamisen hankkimisesta. Tämä nostaa keskiöön nonformaalin ja informaalin oppimisen tunnustamisen.

Ammattikorkeakoulujen tutkinto-ohjelmiin kuvattiin osaamisalueet vuosina 2004-2006. Tämän jälkeen ammattikorkeakoulut jatkoivat itsenäisesti opetussuunnitelmiensa muokkaamista osaamisperusteisiksi. Nyt verkkopedagogiikkaa kehitetään ja opetuksen digitalisaatio etenevät, mutta ovatko osaamisperustaisuuden perusideat selvillä? Osataanko ammattikorkeakouluissa tunnistaa ja tunnustaa opiskelijan eri tavoin ja eri ympäristöissä hankittua osaamista? Onko opiskelijalle tarjolla henkilökohtaisen 
opintopolun mahdollisuuksia ja ammatillista kasvua tukevia kiintopisteitä opintopolun varrella?

Tuon esiin, millaisia merkityksiä opetussuunnitelmalle tuotettiin osaamisperustaisen opetussuunnitelman kehittämisprosessissa Oulun ammattikorkeakoulun (Oamk) tekniikan koulutusalalla vuosina 2009-2011. Toimin tutkimuksen (Laajala 2015) teon ajankohtana kontekstiammattikorkeakoulussa osaamisperustaisen opetussuunnitelman kehittämistehtävissä. Roolini oli omaa työtään tutkivan kehittäjän rooli.

\section{OPETUSSUUNNITELMAN KEHITYKSESTÄ}

Opetussuunnitelma on kaikilla koulutusasteilla ja koulutusmuodoissa olennainen opettajan työn kokonaisuuden jäsentäjä. Opetussuunnitelma ei ole yksiselitteisesti määriteltävissä vaan käsitteellä viitataan sekä prosessiin että dokumenttiin. Se on myös alati muuttuva opetussuunnitelmatutkimuksen tutkimuskohde.

Pinarin ym. (1995, 847-848) mukaan opetussuunnitelma laajimmillaan voidaan nähdä tiettyyn aikaan ja paikkaan sidoksissa olevana symbolisena kamppailuna, jossa eri sukupolvet määrittelevät itsensä ja maailmansa. Se on esitys siitä, mitä arvoja opetussuunnitelman laatijat pitävät tärkeinä, millaisiin päämääriin koulutuksella pyritään sekä mitä ja miten tulee oppia. Ammatillisen koulutuksen opetussuunnitelmien voi lisäksi nähdä representoivan joko eksplisiittisesti tai implisiittisesti kyseisen ammatin arvopohjaa, toisin sanoen sitä, millaista ammattilaista milloinkin pidetään arvokkaana päämääränä. Opetussuunnitelmaan sisältyy aina kysymys, kenellä tai millä taholla on oikeus määritellä, mitä koulutusinstituutioissa tulee opettaa ja opetussuunnitelmalla nähdäänkin olevan poliittinen ulottuvuus (esim. Eggleston 1977; Kelly 2009, 19). Suppeimmillaan opetussuunnitelma on kurssikuvausten lista siitä tiedosta, mitä opiskelijoille tulee välittää (Auvinen ym. 2007, 51; Kelly 2009, 56-57; Lauriala 1984).

Opetussuunnitelman tutkimuksessa on tapahtunut paradigman muutos 1970-1990-luvuilla kuten muutoinkin ihmistieteissä. Uusi ymmärtävä ja tulkinnallinen opetussuunnitelmatutkimus katsoo opetussuunnitelmaa kulttuurisena representaationa, kun aiempi tutkimus keskittyi siihen, miten opetussuunni- telma laaditaan mahdollisimman tehokkaaksi ja rationaaliseksi. (Pinar ym. 1995, 16.) Oppiainesisällöistä lähtevä opetussuunnitelma on saanut rinnalleen yksilöllistä elämänkulkua painottavan ajattelun, joka korostaa postmodernin ihmisen tarvetta ja oikeutta rakentaa identiteettiään osaamisen ja tiedon yksilöllistämisen kautta. Opetussuunnitelma on alettu käsittää neuvotteluksi, johon osallistuvat kaikki osapuolet, joita se koskee. (Doll 1993, 176; Goodson 2009, 71-72; Ropo ym. 2001, 8.)

Opetussuunnitelmatutkimuksen keskeinen tarkastelunäkökulma on opettajan ja opetussuunnitelman välinen suhde. Ymmärtävästä ja tulkinnallisesta opetussuunnitelmateoriasta nouseva tutkimus tarkastelee kriittisesti behavioristiselle oppimisteorialle pohjautunutta tehokkuus- ja tavoiteorientoitunutta opetussuunnitelmaa. Kritiikki on erityisesti kohdistunut siihen, että opettaja nähdään tavoiteorientoituneessa opetussuunnitelmassa sen teknisenä toimeenpanijana, jolla ei ole pääsyä suunnitelman tavoitteiden asettamiseen ja kehittämiseen (Doll 1993; Grundy 1987; Lauriala 2013, 573, Stenhouse 1975). Ymmärtävän ja tulkinnallisen opetussuunnitelmateorian tärkeä tavoite on ollut antaa opettajille ääni opetussuunnitelman kehittäjinä ja sitä koskevan tiedon tuottajina (Lauriala 2013, 758-580).

Osaamisperustaisuuden käsite tuli ammattikorkeakouluihin valtakunnallisen ECTS-hankkeen myötä 2000-luvulla (Arene 2007). Osaamisperustaisuus esiteltiin eurooppalaisen tutkintojen viitekehyksen (EQF) mukaisena tiedot, taidot ja työelämäkompetenssit yhdistävänä osaamisen mallina. Tavoite oli kiinnittää huomiota opetussuunnitelmadokumenttien tapaan ilmaista oppimisen tavoitteet opiskelijan osaamisen kuvauksena eikä aikaisemman oppiainejakoisen opetussuunnitelman tapaan listana opettajalle siitä mitä oppitunneilla tulee käydä läpi (Auvinen ym. 2007, 51). Samalla haluttiin kiinnittää huomiota myös siihen, kuinka pedagogiikankin tulee muuttua opiskelijan oppimista ja osaamisen kehittymistä tukevaksi sekä osaamista tunnistavaksi ja tunnustavaksi.

Osaamisperustaisuus on nähty myönteisenä opiskelijalähtöisenä periaatteena, mutta sitä on myös arvosteltu siitä, että korostaessaan opiskelijan osaamisen näkemistä havaittavana ja arvioitavana käytännön 
toimintana, se tulee luoneeksi yhteyden tavoiteorientoituneeseen behavioristiseen opetussuunnitelmaan. Young $(2013,107-108)$ ja Wheelahan $(2015,750)$ kritisoivat nykyistä länsimaissa yleistä ammatillisen koulutuksen osaamisperustaista opetussuunnitelmaa sanoen sen fokusoivan taitoon (skills) tiedon (knowledge) kustannuksella. Näin osaamisperustaisuus tulee heidän mukaansa eristäneeksi osan opiskelijoista kriittisestä tiedosta ja uusintaneeksi eriarvoisuutta, vaikka eksplisiittinen tarkoitus on edistää inkluusiota ja osallisuutta työmarkkinoilla. Mäkinen ja Annala $(2012$, 132) huomauttavat, että osaamisperustaisuutta ei ole jäsennelty tutkimuksellisesti ja sen paradigmaattiset yhteydet ovat jääneet implisiittisiksi.

\section{TUTKIMUSAINEISTO JA -MENETELMÄ}

Tutkimusaineisto muodostuu osaamisperustaisen opetussuunnitelman kehittämisprosessin aikana vuosina 2009-2011 äänitetyistä keskusteluista. Oamkissa oli lukuvuonna 2008-2009 järjestetty osaamisperustaisen opetussuunnitelman yhteinen koulutus kaikkien koulutusalojen opetussuunnitelmatyöstä vastaaville. Sen aiheita olivat osaamistavoitteiden laadinta, arviointikriteeristön luominen ja oppimisprosessiperustainen opetuksen suunnittelu. Yhteiseen koulutukseen osallistuneiden henkilöiden tehtävänä oli jalkauttaa sama uudistus omiin koulutusyksiköihinsä.

Osaamisperustaisen opetussuunnitelman uudistus toteutettiin tekniikan alalla, josta tutkimusaineisto koottiin, koulutusohjelmavastaavina toimivien opettajien perehdytyskoulutuksena. Perehdytyksen jälkeen osallistujien oli tarkoitus jalkauttaa uudistus omien koulutusohjelmiensa opettajille. Koulutusohjelmavastaavien perehdytyskoulutusistuntoja järjestettiin seitsemän, joista kuusi äänitettiin ja litteroitiin. Osallistujia oli yhteensä 15 henkilöä, määrän vaihdellessa eri kerroilla 7 ja 13 välillä.

Toimin perehdytyskoulutusistuntojen vetäjänä. Istunnot oli suunniteltu vuorovaikutuksellisiksi ja keskusteleviksi tilaisuuksiksi. Koulutusohjelmavastaavat saivat mahdollisimman paljon kysellä, pohtia äänen ja keskustella keskenään. Valmistellut puheenvuorot olivat lyhyitä alustuksia. Opetussuunnitelman kehittämistä pyrittiin lähestymään yhteisen merkitys- neuvottelun (Annala 2007) ja mahdollisimman laajan osallistamisen kautta.

Taustaolettamukseni oli, että opettajien äänen kuuleminen ja heidän käsittämisensä kehittämisen kumppaneiksi (esim. Lauriala 2013, 582) on arvokasta, jotta saadaan mahdollisimman laajasti aitoa palautetta arviointikehikoiden käytettävyydestä ja myös uusia ideoita niiden kehittämiseksi. Nummenmaa tutkijakollegoineen $(2006,137)$ toteaa, että opetussuunnitelman kehittämisprosessissa on tärkeää tuottaa yhteisyyteen perustuva oppimiskumppanuus, jossa eri toimijat, kuten opettajat, opiskelijat ja hallinto ovat mukana. Opetussuunnitelmaprosessi tulee rakentaa reflektiivisen kehittämisen periaatteille, jolloin käytetään hyväksi työntekijöiden omia kokemuksia. (Nummenmaa ym. 2006, 137.) Kiinnostuksen kohteeni oli selvittää koulutusohjelmavastaavien kokemuksia ja käsityksiä osaamisperustaisen opetussuunnitelman kehittämisestä.

Tutkimusmenetelmänä on sosiaaliseen konstruktionismiin pohjautuva diskurssianalyysi. Sen arvioitiin moni-ilmeisyydestään ja teoreettisesta haastavuudestaan huolimatta olevan sopiva tapa analysoida ryhmäkeskustelua ja siinä yhteisesti rakennettavia merkityksiä. Perehdytyskoulutuksessa tuotiin "ylhäältä alas" tiettyjä uudistuksia sisällytettäväksi opetussuunnitelmaan ja omaksuttavaksi käytäntöön, mutta omana pyrkimyksenäni oli yhteisen merkitysneuvottelun ja erilaisten äänten (Annala 2007; Gergen 1999) kuulumisen mahdollistaminen ja samalla käytäntölähtöisen, situationaalisen tiedon yhdistäminen hallinnolliseen tekstiin, jota kautta saataisiin laadukasta teorian ja käytännön yhdistävää tietoa (Lauriala 2013, 581-583).

Tutkimuskysymyksiksi muotoiltiin:

Millaisia merkityksiä ammattikorkeakoulun osaamisperustaisen opetussuunnitelman kehittämisprosessissa rakentuu?

Millä tavoin osaamisperustaisen opetussuunnitelman kehittämisprosessissa rakentuvat merkitykset tuotetaan?

Diskurssianalyysi nähdään väljänä metodologisena viitekehyksenä. Diskurssit voidaan määritellä vakiintuneiksi puhekäytännöiksi, jotka osaltaan rakentavat ja tuottavat ilmiötä, jota ne kuvaavat. Diskurssianalyysi tutkii diskurssien rakentumista sosiaalisissa käytän- 
nöissä ja vuorovaikutuksellisissa konteksteissa tuotettujen tekstien kautta. (Jokinen ym. 1993, 19-20; Phillips \& Hardy 2002, 3-4.) Tärkeimpiä diskurssianalyysin perusolettamuksia ovat kielen käsittäminen seurauksia tuottavaksi ja todellisuutta muokkaavaksi sekä todellisuuden hahmottuminen keskenään kilpailevien merkityssysteemien kenttinä. Myös tutkijan ja tutkimuskohteen välinen suhde nähdään diskurssianalyyttisessa tutkimuksessa konstruktiivisena. Tutkija sekä kuvaa tutkimustulostensa kautta sosiaalista todellisuutta että luo sitä samalla. (Jokinen ym. 1993, 24, 42; Jokinen ym. 1999, 40-41; Parker 1992, 10-11.)

Diskurssin käsitteen rinnalla käytetään toisinaan rinnakkaiskäsitteinä merkityssysteemiä, tulkintarepertuaaria ja kehystä. (Alasuutari 2011, 180; Jokinen ym. 1993, 26-27; 1999, 66-69.) Jokinen kumppaneineen (1993, 26-27) määrittelee sekä diskurssin että tulkintarepertuaarin verrattain ehyeksi merkityssuhteiden systeemiksi, joka rakentuu sosiaalisissa käytännöissä ja samalla rakentaa sosiaalista todellisuutta.

Tutkimuksessani (Laajala 2015) päädyin esittämään analyysin tulokset tulkintarepertuaareina. Tulkintarepertuaarin käsite soveltuu tutkimuksiin, jotka kohdistuvat analysoimaan yksityiskohtaisesti arkisen kielenkäytön vaihtelevuutta (Jokinen ym. 1993 27; Silverman 2014, 321). Gilbertin ja Mulkayn (1984) sekä Potterin ja Wetherellin $(1987,149)$ mukaan tulkintarepertuaarit ovat toistuvasti käytettyjä käsitejärjestelmiä sekä metaforien ja kielikuvien ympärille ryhmittyviä kuvausten ryppäitä, joiden avulla luonnehditaan toimintoja, tapahtumia ja asioita. Repertuaarit rakentuvat esimerkiksi siten, että samasta asiasta tai ilmiöstä puhutaan useammalla eri tavalla, noiden tapojen poiketessa kielelliseltä tyyliltään, kieliopiltaan ja sanastoltaan toisistaan. Ihminen saattaa usein puhuessaan tietystä asiasta käyttää vuorotellen eri repertuaareja, jonka vuoksi hänen asennoitumistaan asiaan on vaikea lokeroida tai kategorisoida esimerkiksi asenne-teorian avulla. (Potter \& Wetherell 1987, 149; Wetherell \& Potter 1992, 102.) Tämän tutkimuksen tuloksina esitettävien repertuaarien voidaan sanoa olevan erilaisia tilanteisesti rakentuvia tapoja puhua opetussuunnitelmasta, jotka samalla muokkaavat sitä koskevia diskursseja.

Tutkimuksen analyysityökalu rakentui mukaillen Jokisen, Juhilan ja Suonisen $(1999,55)$ diskurssiana- lyysin neljää ulottuvuusparia, joiden avulla määriteltiin tutkimuksen painopisteet. Ulottuvuusparit ovat: (1) tilanteisuuden ja kulttuurisen jatkumon välinen suhde (2) merkitysten ja merkitysten rakentumisen tapojen välinen suhde (3) retorisen ja responsiivisen analyysin välinen suhde sekä (4) kriittisen ja analyyttisen diskurssianalyysin välinen suhde.

Ensimmäisellä ulottuvuudella on painopiste tilanteisesti etenevässä aineiston analyysissa. Kulttuurinen jatkumo on myös läsnä ja se luodaan merkityksellistämällä ja tulkitsemalla tekstiä suhteessa opetussuunnitelman diskursseihin ja rakentaen vuoropuhelua aineiston ja teoreettisen kehyksen välille. Toisella ulottuvuudella tarkastellaan sekä rakentuvia merkityksiä että niiden tuottamisen tapoja. Merkitysten tuottamisen tapojen ulottuvuudella ovat läsnä analyysissa sekä vakuuttelun keinoja tarkasteleva retorisuus että puhujien keskinäiseen reagointiin keskittyvä responsiivisuus. Kriittisyys ja analyyttisyys sisältyvät analyysiin, mutta painopiste on enemmän analyyttisyydessä, jolloin keskitytään kuvaamaan sosiaalisen todellisuuden rakentumista. Kriittisyys on kuitenkin mukana siten, että aineistosta nousevat merkitykset ja rakentuvat repertuaarit kiinnitetään laajempiin diskursseihin, jolloin tutkimus omalta osaltaan osallistuu noiden diskurssien muokkaamiseen. (Jokinen ym. 1999 55-90; Laajala 2015, 97.)

\section{TULOKSET}

Tutkimusaineistosta avautui teema, joka käsitteli perehdytyskoulutukseen osallistujien antamia merkityksiä oppimiselle, opetuksen käytänteille, opetussuunnitelmalle, osaamiselle, oppijalle ja työelämäyhteistyölle. Se nimettiin opetussuunnitelman diskurssiksi. Opetussuunnitelman diskurssi heijastelee opetussuunnitelman determinantteja (Lauriala 1984, 22), joihin sisältyy osaamistavoitteiden ja opetussisältöjen lisäksi oppijaa ja työelämäsuhdetta koskeva merkityksellistäminen.

Analysoitaessa opetussuunnitelmaa koskevia vaihtelevia puhetapoja muodostettiin neljä tulkintarepertuaaria: 1) formaalin oppimisen repertuaari, 2) henkilökohtaisen oppimisen repertuaari 3 ) opiskelija kohteena -repertuaari sekä 4) ristiriitainen suhde työelämään -repertuaari. 


\section{Opetussuunnitelman tulkintarepertuaarit}

Kuvaan seuraavaksi opetussuunnitelman tulkintarepertuaarien sisältöä esimerkkien avulla. Sitaatit ovat poimintoja väitöskirjassani (Laajala 2015) esitetyistä pidempiä keskustelujaksoja kattavista aineisto-otteista. Viittaus sitaatin lopussa viittaa alkuperäiseen aineisto-otteeseen.

Formaalin oppimisen repertuaari sisältää keskustelua siitä, missä ja miten voidaan oppia ja hankkia osaamista sekä miten osaamista voidaan tunnistaa ja tunnustaa. Repertuaariin sisältyy käsitys oppimisesta yksin tapahtuvana individualistisena toimintana. Käsitystä sosiaalisesti jaetusta yhteisöllisestä oppimisesta ei aineistossa tuotettu.

"Ja itsenäisestihän niitten täytyy se tentti tehdä, että tenttitilanteessa ne tehtävät ratkaistaan itsenäisesti, muutenhan kysymys on lunttauksesta." (Otteesta 39)

Erilaisissa oppimisympäristöissä ja eri tavoin hankitun osaamisen tunnistamisen ja tunnustamisen diskurssi oli vieras. Painotus oli oman koulun sisällä tapahtuvassa oppimisessa. Läsnäolopakko ja tentti arviointimenetelmänä nousivat esiin opiskelijaan kohdistuvina kontrollin muotoina (Karjalainen 2001, 51-54).

"Nehän on pakollisia, niin kuin jotkut [oppiaineen nimi] labrat. Siellähän on oltava paikalla, jos et kerran ole, niin et saa suoritettua. Minullahan yhtä lailla nämä [opintojakson nimi] labrat,... jokaisen oltava joka kerta paikalla, sillä periaatteella. Jos on pois, niin vuoden päästä pääsee sitten kehiin taas uudestaan." (Otteesta 47)

Keskustelu toi esiin erilaisia tulkintoja teorian ja käytännön välisestä suhteesta. Tietoperusta nousee opetussuunnitelmassa tärkeimmäksi.

"... kyllä se ammatillinen tietoperusta on yli yhdeksänkymmentä prosenttia, sitä luokkaa ja sitten muut on vähän semmoisia lisämausteita... " (Otteesta 54)

Teoria ja käytäntö tuotettiin toisistaan erillisinä tai peräkkäisinä ilmiöinä, jolloin niitä voidaan opettaa eri opintojaksoissa. EQF:n ohjeistuksen mukainen tiedon, taidon ja eettisen toiminnan ulottuvuuden yhdistäminen tietoperustaan keskittyvässä opetussuunnitelmassa on selvästi haastavaa. Rakentunut erillisyyttä ja peräkkäisyyttä korostava teoria-käytäntö-suhde on ilmeisessä ristiriidassa ammattikorkeakoulupedagogiikan pragmatistisen tietoteoreettisen taustan kanssa (Taatila \& Raij 2012).

Opetussuunnitelma tuotettiin opintojaksokeskeisenä keskustelussa, jota käytiin Oamkin uuden arviointikriteeristön käytöstä. Keskustelussa päädyttiin yksinkertaiseen ja teknisesti helpompaan ratkaisuun, jolloin lopputuloksena saattaa olla suppeita opintojaksoja sisältävä opetussuunnitelma, jossa tietoperusta opetetaan yhdessä opintojaksossa ja soveltaminen toisessa.

"Niin että se on jonkin asian sopiva kokonaisuus ja se sijoittuu jollekin näistä tasoista eikä leviä kaikkialle." (Otteesta 75)

Opetussuunnitelman ja oppimisen ymmärtäminen teorian ja käytännön refleksiivisenä vuorovaikutuksena, jota useat tutkijat (Doll 1993, 162; Taatila \& Raij 2012; Grundy 1987,27) korostavat, saattaa tällaisissa ratkaisuissa jäädä huomiotta. Opiskelijan kokemus tiukasti opintojaksoperusteisesta opetussuunnitelmasta voi jäädä pirstaleiseksi, kun opetussuunnitelma ei tee näkyväksi osaamisen kehittymisen ja ammatillisen kasvun polkua eikä tarjoa lähtökohtia henkilökohtaisen opetussuunnitelman laatimiselle, mitä myös Auvinen kollegoineen $(2007,107)$ painottavat.

Esiin noussut substanssikeskeisyys kertoo siitä, että geneeristen kompetenssien integroiminen opetussuunnitelmaan merkityksellistettiin keinotekoisena ja vaikeana. Koetulla hankaluudella voidaan nähdä yhteys aiemmin esiin nostettuun oppiainejakoiseen ja tietoperustaiseen opetussuunnitelmakäsitykseen, jolloin osaaminen rinnastuu tietoon ja osaamisen muut ulottuvuudet sulkeistetaan.

"Voi saada vitosen, että osaa johtaa yhtän mitään, siis meidän systeemissä. Se mittaa vain tietoperustaa." (Otteesta 67)

Ammattispesifiä tietoperustaa korostava substanssilähtöisyys voidaan kytkeä vahvaan oppi- ja tieteenalaan sitoutuneeseen identiteettiin, joka on yleinen 
muun muassa tekniikan alan korkeakoulutuksessa (Korhonen, Nevgi \& Stenlund 2012, 137-141). Heikommassa asemassa sen sijaan on pedagoginen identiteetti, joka antaisi valmiutta oppialojen rajojen ylittämiseen ja yläpuolelle nousemiseen ja kykyä tarkastella oppimista ja oppimisprosesseja yleisinä oppimisen, kasvun ja kehittymisen ilmiöinä.

Henkilökohtaisen oppimisen repertuaari rakentui osaamistavoitteiden laadintaan liittyvän kriittisen reflektion kautta. Repertuaari rakentaa opetussuunnitelmaa andragogisessa ja postmodernissa kehyksessä henkilökohtaisena identiteetin rakennuksen elinikäisenä matkana.

"... mutta minusta häiritsee se, että me lähdetään siitä ajattelusta, että meillä on kaikilla joku sama lähtöpiste ja loppupiste, koska minusta ideaalista on, että kaikki etenee omalla tasollaan. Minusta oppimistilanne on parhaimmillaan, niin että kukin aloittaa omalta tasoltaan ja oikeestihan kaikilla on eri lähtötaso aina." (Otteesta 52)

Henkilökohtaisen oppimisen repertuaari rakentui vain yhdessä keskustelujaksossa, ja sen edistyminen tukahdutettiin yhteen sopimattomana tavoiteorientoituneen perehdytyskoulutuksen kanssa. Perehdytyskoulutuksen työkaluna osaamistavoitteiden laadinnassa käytettiin Bloomin kognitiivisten tavoitteiden taksonomiaa, jonka portaittaiset vaiheet ovat muistaa, ymmärtää, soveltaa, analysoida, arvioida ja luoda uutta tietoa (Anderson \& Krathwohl 2001). Oppimisen henkilökohtaisuutta korostava näkökulma ei sen sijaan kuulunut koulutuksen sisältöön.

Opiskelija kohteena -repertuaari rakentui opiskelijoita koskevasta puhetavasta. Opiskelijapuhe oli pessimististä ja determinististä: kaikilla opiskelijoilla ei ole kykyä oppia kaikkia tutkintoon kuuluvia asioita. Opiskelija tuotettiin passiivisena, vastuuttomana, sitoutumattomana ja ei-täysivaltaisena, joka sulkeistaa itsensä omaa oppimistaan koskevasta keskustelusta.

"... se on kyllä kyseenlaista katsooko se opiskelija [opetussuunnitelmaa], vaikka nämä on opiskelijoita varten tehty." (Otteesta 82)

Opiskelijaa ei tuotettu keskusteluissa konstruktivistisessa oppijalähtöisyyden kehyksessä itseohjautu- vana toimijana ja oppimisen tasavertaisena kumppanina. Oppijalähtöisyyden lisääminen oli osaamisperustaisen opetussuunnitelman keskeinen tavoite (Arene 2007); näiltä osin julkipuhe ja käytäntö ovat ristiriidassa keskenään.

Ristiritainen suhde työelämään -repertuaarissa näyttäytyy ammattikorkeakoulun opettajan työelämäsuhde reaktiivisena, työelämän muutoksia ja kehittymistä sivusta seuraavana ja muutoksia opetussuunnitelmassa huomioimaan pyrkivänä sekä jopa työelämäyhteistyön torjuvana ja opetukseen keskittyvänä. Työelämä kuvautuu alati muuttuvana ja hektisenä irrationaaliseksikin koettuja muutospaineita esittävänä.

"... jos se [substanssiosaaminen] puuttuisi, niin nämä johtajat olis vähän ihmeissään, ne vaan haluaa kaikkea." (Otteesta 86)

Työelämälähtöisyys on tärkeä ammattikorkeakoulun toiminnan lähtökohta, mutta vastavuoroinen kehittävä kumppanuus- ja yhteistyösuhde ei noussut keskusteluissa esille. Opettajien lähtökohtana työnsä tarkastelulle saattaakin edelleen olla opetustehtävä, kuten Mäki $(2012,91)$ arvelee. Tämä poikkeaa ammattikorkeakoulun julkitavoitteisiin sisältyvistä näkökulmista, mihin ristiriitaan repertuaarin nimi viittaa.

\section{YHTEENVETOA TULOKSISTA}

Osaamisperustaisen opetussuunnitelman kehittämisprosessin tavoitteena tutkimuskontekstissa oli edistää opetussuunnitelman osaamisperustaisuutta ja lisätä oppijalähtöisyyttä. Tutkimuksen tuloksena rakentuneen formaalin oppimisen repertuaarin syntyminen tuo esiin, että kehittämisprosessissa ei osaamista ja osaamisperustaisuutta koskevissa tulkinnoissa päästy juurikaan tietoperustaa syvemmälle. Perehdytyskoulutuksen pohjauduttua Bloomin taksonomian tiedon prosessoinnin tasojen kuvauksille, fokusoitui työskentely tiedollisiin osaamistavoitteisiin. EQF:n tiedot, taidot ja työelämäkompetenssit integroiva osaamisen malli oli vaikea yhdistää oppiainekeskeisen ja tietoperustaisen opetussuunnitelmamallin kanssa. 
Tuloksista voi päätellä, että opetussuunnitelmaajattelu ei ole muuttunut konstruktivistiseksi siirryttäessä opistoasteelta ammattikorkeakouluun, vaikka ammattikorkeakoulu-uudistuksesta on kulunut jo pari vuosikymmentä. Osaamisperustainen pedagogiikka näyttää tutkimuskontekstissa olevan vielä alkuvaiheessa.

Esiin nousee myös, että aiemmin hankitun osaamisen tunnistamisen ja tunnistamisen ajatus on vieras. Oppimisen käsittäminen kaikkialliseksi, johon sisältyy ajatus koko ajan, eri tavoin ja erilaisissa oppimisympäristöissä tapahtuvasta oppimisesta (Kumpulainen, Krokfors, Lipponen, Tissari, Hilppö, \& Rajala 2010, 93), ei kuulu formaaliin opetussuunnitelmaan, vaan painotus on koulun seinien sisällä tapahtuvassa oppimisessa. Opiskelija kohteena -repertuaarin rakentuminen formaalin opetussuunnitelmakäsityksen yhteydessä johtaa pohtimaan, mitä haasteita oppijalähtöisyyden edistämisellä todellisuudessa on, silloin kun opiskelija tuotetaan passiivisena ja opintoihin sitoutumattomana.

Bloomin taksonomian käyttäminen osaamistavoitteiden muotoilun taustatyökaluna saattaa osittain vaikuttaa tutkimuksen tuloksiin. Jos perehdytyskoulutus olisi pohjautunut erilaiselle lähestymiselle, olisivat tuloksetkin muodostuneet todennäköisesti toisenlaisiksi. Arvioitaessa tutkimuksen tuloksia on lisäksi muistettava, että laadullisessa tutkimuksessa tulokset syntyvät tutkijan tulkintatyön tuloksena.

Tulkintaresurssini tutkijana nousevat koulutukseni ja ammattini kautta omaksutusta konstruktivistiselle paradigmalle rakentuvasta kasvatustieteellisestä kehyksestä kun taas tutkimukseen osallistujat edustivat teknillis-luonnontieteellisiä tieteitä. Olin tutkimusta tehdessäni kyseisen työyhteisön pitkäaikainen jäsen, minkä voi erilaisesta taustasta huolimatta ajatella parantavan tulkinnan pätevyyttä.

\section{POHDINTAA}

Tulokset tarjoavat mahdollisuuden pohtia, mihin suuntiin ammattikorkeakoulun opetussuunnitelman kehittämistä olisi hyvä kohdentaa. Osaamisen käsite vaatisi paljon syventämistä, jotta opetussuunnitelma tulisi rakennettua alusta lähtien osaamisperustaisek- si ja vietäisiin myös pedagogisiin käytäntöihin asti. Opetussuunnitelma ei ole osaamisperustainen, jos tavoitteet on "käännetty osaamiskielelle", mutta toiminta jatkuu opettajalähtöisenä formaalia oppimista painottavana.

Oppimisen kaikkiallisuuden käsitteellinen selventäminen olisi myös tärkeää. Tämä tarkoittaa, että oppimisen henkilökohtaisuus ja ammatillinen kasvu nostetaan ammattikorkeakoulun opetussuunnitelman keskiöön. Tällöin opetussuunnitelma nähtäisiin ensisijaisesti eksplisiittisenä ja tietoisena kuvauksena ammattiin kasvamisen mahdollisuudesta. Tämä luo myös pohjan informaalin ja nonformaalin oppimisen ymmärtämiselle.

Osaamisperustaisuuden tulkinnassa on tärkeää pyrkiä varmistamaan, että siihen sisältyy korkeatasoinen ja moniulotteinen asiantuntijaosaaminen (Mäkinen \& Annala 2012, 138) ja irrottautua näkemyksestä, jossa osaaminen tulee nähdyksi yksittäisinä ja irrallisina tehtävinä minimivaatimusten mukaisesti (Haltia 2011, 61). Kysymys kytkeytyy oppimisen henkilökohtaisuuteen: nähdäänkö ammattiin oppiminen kaikille yhtenäisten minimistandardien läpäisynä vai jokaiselle oppijalle hänen omista lähtökohdistaan yksilöllisesti rakentuvana elinikäisenä ammatillisen kasvun polkuna.

Opetussuunnitelman lähtökohtana tulisi olla dynaaminen ja kumppanuuteen perustuva työelämälähtöisyys (Annala \& Mäkinen 2011, 16; Korhonen ym. 2012, 135). Yhteisöllisen opetussuunnitelman käsite (Haarala, Keto \& Sipari 2008, 155) sopii hyvin erilaisten innovatiivisten työelämäprojektien suunnittelun lähtökohdaksi. Se antaa ideana hyviä suuntaviivoja työelämäsuhteen rakentamiselle ja siihen sisältyvien ristiriitojen ylittämiselle.

Opetussuunnitelma käsitteenä ja toimintana ei uudistu, ellei opiskelijan osuutta painoteta oppimiskumppanuudessa. On tärkeää nähdä opiskelijat kykenevinä osallistumaan täysivaltaisina toimijoina oman oppimisensa suunnitteluun. Heille tulisi tarjota mahdollisuus asteittain syvenevään osallistumiseen omassa oppimisyhteisössään. Osallisuus etenee tukea antavien "tikapuiden" tarjoamisesta asiantuntijakulttuuriin integroitumiseen ja ammatillisen identiteetin rakentamiseen (Kukkonen 2012, 166). 
Opetussuunnitelman tulisi olla jatkuvasti avoin opiskelijoiden kysymyksille ja huomioille. Keskustelua opetussuunnitelmasta tulisi käydä koko ajan useilla eri tasoilla, niin että myös opintopolun alussa olevat opiskelijat sosiaalistuvat keskustelun kulttuuriin ja rohkenevat osallistua siihen. Kysymys on opettajien ja opiskelijoiden yhteisestä käytäntöä reflektoivasta dialogista ja opetussuunnitelman kehittämisestä.
Tiina Laajala

$K T$, Lehtori

Ammatillinen opettajakorkeakoulu

Oulun ammattikorkeakoulu

\section{LÄHTEET}

Alasuutari, P. (2011). Laadullinen tutkimus. Tampere: Vastapaino.

Anderson, L. W. \& Krathwohl, D. (toim.) (2001). A taxonomy for learning, teaching, and assessing: A revision of Bloom's taxonomy of educational objectives. New York: Longman.

Annala, J. (2007). Merkitysneuvotteluja hopsista. Toimintatutkimus hopsin ja sen ohjauksen kehittämisestä korkea-asteen koulutuksessa. Acta Electronica Universitatis Tamperensis 611. Tampereen yliopisto. Opettajankoulutuslaitos. Väitöskirja.

Annala, J. \& Mäkinen, M. (2011). Korkeakouluopetuksen opetussuunnitelma - kohti tietämisen ja taitamisen päämääriä. Kasvatus 42(1), 6-18.

Arene (2007). Ammattikorkeakoulut Bolognan tiellä. Ammattikorkeakoulujen osallistuminen eurooppalaiseen korkeakoulutukseen. Projektin loppuraportti. Ammattikorkeakoulujen rehtorineuvosto. Helsinki: Arene.

Auvinen, P., Dal Maso, R., Kallberg, K., Putkuri, P., \& Suomalainen, K. (2007). Opetussuunnitelma ammattikorkeakoulussa. Pohjois-Karjalan ammattikorkeakoulun julkaisuja B: Selosteita ja opetusmateriaalia, 9.

Doll, W. Jr. (1993). A Post-modern perspective on curriculum. New York: Teachers College Press.

Eggleston, J. (1977). The sociology of the school curriculum. London: Routlege \& Kegan Paul.

Gergen, K. (1999). An invitation to social construction. London: Sage.

Goodson, I. F. (2009). Curriculum, narrative and the social future. Teoksessa E. Ropo ja T. Autio (toim.) International conversations on curriculum studies. Subject, society and curriculum. Rotterdam: Sense, $71-85$

Grundy, S. (1987). Curriculum: Product or praxis. London: Falmer.
Haarala, P., Keto, A. \& Sipari, S. (2008). Yhteiskehittelyllä paradoksien hyödyntämiseen. Innovaatioprojektiopintojen suunnittelu. Teoksessa A. Töytäri-Nyrhinen (toim.) Osaamisen muutosmatkalla. Helsinki: Edita, 142-163.

Haltia, P. (2011). Toimivaan osaamisperustaisuuteen. Ammattikasvatuksen aikakauskirja 13 (4), 57-67.

Jokinen, A., Juhila, K. \& Suoninen, E. (1993). Diskurssianalyysin aakkoset. Tampere: Vastapaino.

Jokinen, A., Juhila, K. \& Suoninen, E. (1999). Diskurssianalyysi liikkeessä. Tampere: Vastapaino.

Karjalainen, A. (2001). Tentin teoria. Oulun yliopiston opetuksen kehittämisyksikön julkaisuja, Dialogeja 4/2001.

Kelly, A. V. (2009). The curriculum. Theory and practice. London: Sage Publications.

Korhonen, V., Nevgi, A. \& Stenlund, A. (2012). Pedagogisen johtamisen ja yhteisten oppimiskäsitysten luomisen haasteet korkeakoulujen muutoksessa. Teoksessa M. Mäkinen, V. Korhonen, J. Annala, P. Kalli, P. Svärd ja V.-M. Värri (toim.) Korkeajännityksiä Kohti osallisuutta luovaa korkeakoulutusta. Tampere: Tampere University Press, 130-151.

Kukkonen, H. (2011). Positiointi opetussuunnitelman ymmärtämisen välineenä. Teoksessa M. Mäkinen, V. Korhonen, J. Annala, P. Kalli, P. Svärd ja V.-M. Värri (toim.) Korkeajännityksiä - Kohti osallisuutta luovaa korkeakoulutusta. Tampere: Tampere University Press, 83-103.

Kumpulainen, K., Krokfors, L., Lipponen, L., Tissari, V., Hilppö, J., \& Rajala, A. (2010). Oppimisen Sillat - Kohti osallistavia oppimisympäristöjä. Helsinki: Yliopistopaino. Saatavilla: http://hdl. handle. net/10138/15628. Viitattu 21.4.2016.

Laajala, T. (2015). Diskurssianalyyttinen tutkimus ammattikorkeakoulun opetussuunnitelman kehittämisprosessista. Lapin yliopisto. Kasvatustieteiden tiedekunta. Acta Universitatis Lapponiensis 309. Väitöskirja. 
Lauriala, A. (1984). Opetussuunnitelman määräytymisen tarkastelu ja sen merkitys opettajan työlle lähinnä yleissivistävässä perusasteen koulutuksessa.

Oulun yliopisto. Kasvatustieteiden tiedekunta. Lisensiaattitutkielma.

Lauriala, A. (2013). Changes in research paradigms and their impact on teachers and teacher education: A Finnish case. Teoksessa C. Craig, P. Meijer ja J. Broeckmans (toim.) From teacher thinking to teachers and teaching: The evolution of a research community. Advances in Research on Teaching 19. Bingley, UK: Emerald, 569-595.

Mäki, K. (2012). Opetustyön ammattilaiset ja mosaiikin mestarit. Työkulttuurit ammattikorkeakouluopettajan toiminnan kontekstina. Jyväskylän yliopisto. Jyväskylä Studies in Business and Economics 109. Väitöskirja.

Mäkinen, M. \& Annala, J. (2012). Osaamisperustaisen opetussuunnitelman kahdet kasvot. Teoksessa M. Mäkinen, V. Korhonen, J. Annala, P. Kalli, P. Svärd ja V.-M. Värri (toim.) Osallistava korkeakoulutus. Tampere: Tampere University Press, 127-151.

Nummenmaa, A-R., Karila, K., Virtanen, J. \& Kaksonen, H. (2006). Opetussuunnitelma työyhteisön neuvottelun ja työssäoppimisen kohteena. Teoksessa A.-R. Nummenmaa (toim.) Opettajan työ ja oppiminen. Jyväskylä: Koulutuksen tutkimuslaitos, 126-137.

Pinar, W. F., Reynods, W. M., Slattery, P. \& Taubman, P. M. (1995). Understanding curriculum. An introduction to the study of historical and contemporary curriculum discourses. New York: Peter Lang.

Pinar W. F. (2012). What is curriculum theory? Second Edition. New York: Routledge.

Ropo, E. \& Huopanainen, M. (2001). Havaintoja opettajien ja rehtoreiden kokemuksista opetussuunnitelmaprosessin vaiheista peruskoulussa. Teoksessa E. Ropo (toim.) Opettajuus ja opetussuunnitelma koulun muutoksessa. Tampereen yliopisto. Opettajankoulutuslaitoksen julkaisuja A 24/2001, 77-99.

Silverman, D. (2014). Interpreting qualitative data. London: Sage.

Stenhouse, L. (1975). An introduction to curriculum research and development. London: Heinemann.

Taatila, V. \& Raij, K. (2012). Philosophical review of pragmatism as a basis for learning by developing pedagogy. Educational Philosophy and Theory 44(8), 831-844.

Wetherell, M, \& Potter, J. (1992). Mapping the language of racism. Discourse and the legitimation of exploitation. Cornwall: Harvester Wheatsheaf.

Wheelahan, L. (2015). Not just skills: what a focus on knowledge means for vocational education. Journal of Curriculum Studies 47(6), 750-762

Young, M. (2013). Overcoming the crisis in curriculum theory: a knowledge-based approach. Journal of Curriculum Studies 45(2), 101-118. 